\title{
Pengaruh Penerapan Sistem Pengendalian Manajemen Pada Pendapatan Dan Biaya Terhadap Kinerja Keuangan Klinik Mitra Medika Rancaekek Di Masa Pandemi COVID-19
}

\section{Melda Sagita ${ }^{1}$, Sherien Leni Hamdati ${ }^{2}$, Anoegrah Noerwulantari ${ }^{3}$, Muhammad Ardi Nupi Hasyim ${ }^{4}$}

\author{
Institut Manajemen Koperasi Indonesia, Kawasan Pendidikan Tinggi Jatinangor \\ ${ }^{1}$ meldasagita77@gmail.com, ${ }^{2}$ Sherienlenihmd24@gmail.com, ${ }^{3}$ Anoegrahnoer@gmail.com, \\ 4ardi.nupi@yahoo.com
}

\begin{abstract}
Abstrak
Klinik Mitra Medika merupakan perusahaan yang bergerak di bidang kesehatan umum rawat jalan. Selama ini Klinik Mitra Medika belum menerapkan sistem pengendalian manjemen yang baik dalam mengukur kinerja keuangan perusahaan dari aspek laporan keuangan. Penulis bertujuan untuk mengukur kinerja keuangan Klinik Mitra Medika Rancaekek dengan penerapa sistem pengendalian manajemen yang sesuai dengan kondisi saat pandemi. Dengan menggunakan metode kuantitatif peneliti membandingkan laporan keuangan dari tahun ketahun serta penerapan pegendalian manajemen keuangan yang baik dari beberapa indikator. Maka diperoleh kesimpulan: (1) Tanggung jawab yaitu mampu memenuhi tanggung jawabnya kepada lembaga keuangan dan laporan keuangan. (2) Kemampuan memenuhi kewajiban, dalam memenuhi kewajiban perusahaan membayar gaji karyawan dan mampu memenuhi kebutuhan operasional klinik. (3) Kejujuran karyawan dengan mengukur kejujuran dalam pembuatan laporan keungan. (4) Efektifitas dan efesiensi perusahaan diukur dengan tingkat indikator lain sehingga menghasilkan tingkat efektifitas dan efesiensi yang tinggi. (5) Pengendalian Manajemen karyawan dalam kewajiban melaksanakan job description nya.
\end{abstract}

Kata Kunci : Kinerja Keuangan, Skala likert, Klinik Mitra Medika.

\begin{abstract}
Mitra Medika Clinic is a company engaged in outpatient general health. Mitra Medika Clinic has not managed a good management system in measuring company performance from the aspect of financial statements. The author aims to measure the financial performance of Mitra Medika Rancaekek Clinic by implementing a management system appropriate to the conditions during a pandemic. By using quantitative methods, researchers compare financial reports from year to year and the application of good financial management from several indicators. Then the conclusions are obtained: (1) Responsibilities that are able to fulfill their responsibilities to financial institutions and financial reports. (2) Ability to fulfill obligations, in fulfilling company obligations to pay salaries and be able to meet the operational needs of the clinic. (3) Employee honesty by measuring honesty in making financial reports. (4) The effectiveness and efficiency of the company is measured by the level of other indicators so as to produce a high level of effectiveness and efficiency. (5) Management control of employees in carrying out the job description.
\end{abstract}

Keyword :Financial Performance, Scala likert, Mitra Medika Clinic

\section{PENDAHULUAN}

Pada akhir Desember 2019, ditemukan wabah penyakit menular disalah satu kota di Negara China yaitu di Kota Wuhan. Virus ini diumumkan dengan nama Covid-19, yang tingkat penyebarannya sangat pesat hampir ke seluruh dunia termasuk Indonesia dengan waktu yang sangat cepat. Virus Covid19 menyerang Indonesia sejak Maret 2020. Virus Covid-19 merupakan penyakit yang menyerang sindrom pernapasan manusia dan hewan juga dapat menyebabkan infeksi pernapasan berat (SARS-CoV-2). Tercatat dari 
Maret 2020 hingga Maret 2021, Indonesia telah melaporkan 1,47 juta kasus positif yaitu dengan 1,3 juta orang telah sembuh, menyisakan 39,865 kasus yang meninggal dunia.Pandemi Virus Covid-19 atau Corona menyebabkan dampak yang kurang baik hampir seluruh sektor terkena dampak dari Virus ini. Tidak hanya sektor kesehatan, sektor ekonomi juga mengalami dampak serius akibat pandemi virus corona serta menyebabkan perubahan-perubahan kondisi diberbagai negara yang terkena Pandemi ini. Perubahan kondisi ini mencakup beberapa aspek diantaranya kesehatan, pendidikan, sosial ekonomi dan ekonomi hingga mengubah kehidupan aktivitas sehari-hari. Aspekaspek ini membuat situasi di Indonesia memburuk.

Ekonomi dibidang kesehatan yang tersebar di Indonesia salah satunya adalah Klinik. Klinik adalah pusat kesehatan umum kecil yang didirikan untuk merawat pasien, dan biasanya klinik menangani pasien dengan penyakit ringan seperti deman.

Perekonomian dibidang kesehatan ini mengalami penurunan situasi tersebut tidak hanya terjadi pada klinik kesehatan tetapi juga terjadi pada rumah sakit besar yang berada di Indonesia. Semua rumah sakit menghadapi persoalan yang sama. Pendapatan yang menurun berdampak pada arus kas (cash flow) pada klinik kesehatan dan rumah sakit. Arus kas yang terganggu menjadikan beban operasional rumah sakit meningkat.

Pandemi Covid-19 telah mempengaruhi operasional bagi klinik rujukan Covid-19, serta melonjaknya kebutuhan obat, APD, dan kebutuhan lainnya karena virus Covid-19 yang semakin meningkat menjadikan arus kas menurun. Sebab, pendapatan klinik 50\% tidak lagi mencukupi biaya operasional. Belum lagi penurunan kunjungan pasien non-Covid-19 yang menurun drastis,ditambah persoalan dispute klaim dan belum ada kejelasan kapan berakhir masa pandemi Covid-19.

Dewasa ini sejalan dengan bertambahnya jumlah kasus Covid-19 yang terus meningkat, klinik mengalami perubahan yang signifikan baik dalam pendapatan serta pengelolaan keungan yang harus menyesuaikan dengan keadaan sekarang. Kondisi ini membuat beberapa klinik harus memutar balikan strategi dalam pengelolaan kuangan.

Klinik Mitra Medika sebagai suatu badan usaha yang bergerak dibidang kesehatan, yang mengalami penurunan pendapatan karena dampak dari Covid19. Dalam hal ini, sangat diperlukan peranan manajemen dalam pengelola keuangan dan pihak yang menentukan kebijakan yang tepat dalam pengelolaan keuangan serta mendapatkan laba yang optimal. Salah satu cara yang dapat dilakukan pihak klinik adalah dengan melakukan analisis terhadap laporan keuangan dan menyesuaikan dengan kebutuhan. Dengan mengadakan analisis terhadap keuangan akan dapat diketahui atau akan diperoleh gambaran tentang kinerja keuangan klinik tersebut.

Dari data yang kami dapat, pendapatan Klinik Mitra Medika Rancaekek mengalami penurunan dari tahun ke tahun. Hal ini diakbitkan adanya beberapa permasalahan dalam pengelolaan keungan, seperti adanya jaminan sosial kesehatan bagi masyarakat yang kurang mampu yang membuat klinik harus semakin pintar mengelola keuangan. Ditambah dengan adanya pandemi Covid-19 yang sedang berlangsung, penurunan angka pasien Non-Covid berkurang. Tahun sebelumnya laba yang di hasilkan dapat mencapai angka Rp.300.000.000 sampai Rp.350.000.000 dalam setahun. Tetapi ditengah pandemi covid ini Klinik Mitra Medika hanya mendapatkan laba 50\% dari pendapatan sebelumnya. 
Berikut adalah rincian pendapatan, pengeluaran dan laba dari Klinik Mitra Medika Rancaekek dalam empat tahun terakhir:

\begin{tabular}{|c|c|c|c|}
\hline $\begin{array}{c}\text { Tah } \\
\text { un }\end{array}$ & $\begin{array}{c}\text { Pendapa } \\
\tan \end{array}$ & $\begin{array}{c}\text { Pengelu } \\
\text { aran }\end{array}$ & Laba \\
\hline & Rp. & Rp. & Rp. \\
201 & 900.000. & 480.000. & 420.000. \\
7 & 000 & 000 & 000 \\
\hline & Rp. & Rp. & Rp. \\
201 & 720.000. & 300.000. & 420.00 .0 \\
8 & 000 & 000 & 00 \\
\hline & Rp. & Rp. & Rp. \\
201 & 648.000. & 300.000. & 348.000. \\
9 & 000 & 000 & 000 \\
\hline & Rp. & Rp. & Rp. \\
202 & 468.000. & 204.000. & 264.000. \\
0 & 000 & 000 & 000 \\
\hline
\end{tabular}

Berdasarkan permasalahan diatas maka penulis bertujuan untuk mengukur kinerja keuangan Klinik Mitra Medika Rancaekek dengan penerapan sistem pengendalian manajemen yang sesuai dengan kondisi saat pandemi.

Pengendalian manajemen menurut Maciariello (1994:5) “A management control system attempts to bring unity of purpose of the diverse efforts multitude of organizational sub units so as to steer the overall organization and its manager toward its objectives and goals. An management control system of a structure and process". Menurut pengertian diatas Maciariello (1994:5) menyatakan bahwa struktur manajemen bertujuan untuk menyelaraskan kebijakan berbagai perusahaan, organisasi dan organisasi manajemen yang terdiri dari struktur dan proses. Struktur manajemen untuk mencapai tujuan organisasi yang di kemukakan oleh Simons (1990:127) berhubungan dengan bagaimana manajer menggunakan perencanaan dan system manajemen untuk memandu mereka.

Stukur sistem pengendalian manajemen mencangkup pada kinerja manajerial perusahaan termasuk kinerja pengelolaan keuangan. Menurut Devas (2007:279) pengelolaan keuangan merupakan kegiatan yang mengurus dan mengatur keuangan dilandasi dengan prinsip-prinsip sebagai berikut:

1. Tanggung jawab (accountability), Organisasi harus mempertanggungjawabkan keuangannya kepada lembaga atau orang yang berkepentingan yang sah, yaitu lembaga atau orang dan masyarakat umum.

2. Mampu memenuhi kewajiban keuangan, pengelolaan keuangan harus ditata dan dikelola sedemikian rupa sehingga mampu melunasi semua kewajiban keuangan baik jangka pendek, jangka panjang maupun pinjaman jangka panjang pada waktu yang telah ditentukan.

3. Kejujuran, semua hal yang menyangkut pengelolaan keuangan pada prinsipnya harus diserahkan kepada pegawai yang betul-betul jujur dan dapat dipercaya.

4. Hasil guna (efektifitas) dan daya guna (efisiensi) merupakan tata cara mengurus keuangan dengan sedemikian rupa sehingga kegiatan yang direncanakan dapat dilak-sanakan untuk mencapai tujuan dengan biaya yang serendah-rendahnya dan dalam waktu yang secepatcepatnya.

5. Pengendalian, karyawan yang bertugas sebagai pengelola keuangan dan pengawasan keuangan harus melakukan pengendalian agar semua tujuan tersebut dapat tercapai.

Pengelolaan manajemen keuangan adalah proses mendapatkan, mengelola dan menggunakan dana dalam suatu organisasi/perusahaan. Sardjito (2004:43) menyatakan, "Dalam 
pengelolaan keuangan atau dalam beberapa literatur, yang disebut pembelanjaan adalah pekerjaan perusahaan yang berkaitan dengan perolehan, penggunaan, dan pengelolaan asset sesuai dengan kebijakan yang telah ditetapkan oleh perusahaan."

Kinerja keuangan merupakan suatu kondisi yang menggambarkan keadaan keuangan perusahaan dalam periode tertentu yang mencangkup pemasukan dan pengeluaran dana, yang diukur dengan standar kecukupan modal, kemampuan membayar kewajiban, dan kemampuan menghasilkan laba (Jumingan, 2006:239).

\section{METODE}

Penelitian ini bertujuan untuk mengetahui informasi mengenai pengaruh penerapan sistem pengendalian manajemen pada pendapatan dan biaya terhadap kinerja keuangan Klinik Mitra Medika Rancaekek di masa Pandemi Covid-19. Dengan itu teknik analisis dalam penelitian ini menggunakan statistik deskriptif kuantitatif, dilihat dari tujuannya dalam penelitian ini bermaksud menemukan ada tidaknya pengaruh manajemen terhadap kinerja pengelolaan keuangan klinik.

Menurut Sugiyono (2013:13), metode penelitian kuantitatif dapat diartikan sebagai metode penelitian yang didasarkan pada filosofi positivisme, diterapkan pada populasi (kumintas) atau sampel tertentu, teknik pengambilan sampel pada dilakukan secara acak, dan pengumpulan data menggunakan analisis data bersifat kuantitatif/statistik.

Penelitian ini dilakukan di Klinik Mitra Medika Rancaekek Jln. Raya Bandung-Garut No.187 Rt. 01 Rw.08 Desa Mekargalih Kecamatan Jatinangor, Kabupaten Sumedang Jawa Barat.
Infomasi dan data yang dibutuhkan dalam penelitian ini akan menggunakan data sebagai berikut :

1. Data primer : data yang diperoleh secara langsung dari sumbernya, diamati dan dicatat untuk pertama kalinya.

2. Data sekunder : data yang dibutuhkan diusahakan sendiri pengumpulannya oleh peneliti.

Pengumpulan data yang digunakan dalam penelitian ini :

1. Obsevasi

Observasi adalah proses mengidentifikasi suatu objek untuk mengetahui informasi yang diperlukan saat proses menganalisis. Sehingga data yang didapatkan akurat dan sesuai dengan fakta yang ada dilapangan.

2. Wawancara

Wawancara merupakan pertemuan dua orang untuk bertukar informasi melalui tanya jawab sehingga mendapatkan data yang akurat untuk topik tertentu.

3. Kuisioner

Kuesioner adalah metode pengumpulan data dengan cara mengajukan pertanyaan tertulis kepada responden. Kuisioner dalam penelitian ini bersifat tertutup yaitu hanya menjawab pertanyaan-pertanyaan dengan memberikan tanda silang terhadap jawaban-jawaban yang tersedia yang dianggap sesuai.

Setelah pengumpulan data selesai, kemudian dilakukan pengelolaan data menggunakan analisis statistik sederhana dengan memberikan skor terhadap masing-masing jawaban menggunakan skala likert. 
Skoring tersebut memliki skala 1 sampai 5 dengan keterangan sebagai berikut :

$$
\begin{array}{ll}
\text { SB }=\text { Sangat Baik } & 5 \\
\text { B }=\text { Baik } & 4 \\
\text { CB }=\text { Cukup Baik } & 3 \\
\text { KB }=\text { Kurang Baik } 2 & \\
\text { TB }=\text { Tidak Baik } & 1
\end{array}
$$

Skor tersebut diolah menjadi presentase menggunakan rumus sebagai berikut :

$$
P=\frac{\Sigma n}{\Sigma N} \cdot 100 \%
$$

Keterangan :

$\mathrm{P} \quad=$ Presentasi

$\sum \mathrm{n}=$ Skor yang diperoleh

$\sum \mathrm{N}=$ Skor maksimum

Hasil dari presentase penelitian dikelompokan menggunakan kriteria kualitas sebagai berikut :

1. Sangat baik : $80 \% \leq \mathrm{P} \leq 100 \%$

2. Baik $: 60 \% \leq \mathrm{P}<80 \%$

3. Cukup baik : $40 \% \leq \mathrm{P}<60 \%$

4. Kurang baik : $20 \% \leq \mathrm{P}<40 \%$
HASIL

\section{Karakteristik Responden}

Tabel 1. Karakteristik Responden Berdasarkan Jabatan di Klinik

\begin{tabular}{|c|c|c|}
\hline Jabatan & Jumlah & Persentase \% \\
\hline Dokter & 3 & $50 \%$ \\
\hline Perawat & 2 & $33 \%$ \\
\hline $\begin{array}{c}\text { Pengelola } \\
\text { keuangan }\end{array}$ & 1 & $17 \%$ \\
\hline Total & 6 & $100 \%$ \\
\hline
\end{tabular}

Berdasarkan tabel 1 diketahui bahwa responden terbanyak adalah yang memiliki jabatan sebagai Dokter yaitu 3 orang $(50 \%)$.

Tabel 2. Karakteristik Responden Berdasarkan Jenis Kelamin

\begin{tabular}{|c|c|c|}
\hline $\begin{array}{c}\text { Jenis } \\
\text { Kelamin }\end{array}$ & Jumlah & $\begin{array}{c}\text { Persentase } \\
\%\end{array}$ \\
\hline Laki-Laki & 4 & $67 \%$ \\
\hline Perempuan & 2 & $33 \%$ \\
\hline Total & 6 & $100 \%$ \\
\hline
\end{tabular}

Berdasarkan tabel 2 diketahui sebagian besar dari responden berjenis kelamin laki-laki yaitu 4 orang (67\%) dan sisanya berjenis kelamin perempuan sebanyak 2 orang (33\%). 


\section{Hasil Pengelolaan Data}

\section{Tabel 3. Hasil Pengukuran Kinerja}

\begin{tabular}{|c|l|c|c|c|c|}
\hline No & Sub Variabel & $\begin{array}{c}\text { Skor yang } \\
\text { di dapat }\end{array}$ & $\begin{array}{c}\text { Skor } \\
\text { Maksimal }\end{array}$ & Presentase \% & Kategori \\
\hline 1 & Tanggung Jawab & 24 & 30 & $80 \%$ & $\begin{array}{c}\text { Sangat } \\
\text { Baik }\end{array}$ \\
\hline 2 & $\begin{array}{l}\text { Kemampuan } \\
\text { memenuhi } \\
\text { kewajiban }\end{array}$ & 23 & 30 & $77 \%$ & $\begin{array}{c}\text { Baik } \\
\text { Kejujuran } \\
\text { Karyawan }\end{array}$ \\
\hline 4 & $\begin{array}{l}\text { Efektifitas dan } \\
\text { efisiensi modal }\end{array}$ & 24 & 30 & $80 \%$ & $\begin{array}{c}\text { Sangat } \\
\text { Baik }\end{array}$ \\
\hline 5 & $\begin{array}{l}\text { Pengendalian } \\
\text { manajemen }\end{array}$ & 26 & 30 & $87 \%$ & $\begin{array}{c}\text { Sangat } \\
\text { Baik }\end{array}$ \\
\hline Total Keseluruhan & 124 & 150 & $83 \%$ & $\begin{array}{c}\text { Sangat } \\
\text { Baik }\end{array}$ \\
\hline
\end{tabular}

Dari tabel 3 diperoleh hasil dari tiap item pertanyaan dikategorikan sangat baik. Persentase tertinggi terdapat pada pertannyaan kejujuran karyawan yaitu $90 \%$.

\section{PEMBAHASAN}

Berdasarkan penelitian di Klinik Mitra Medika Rancaekek yang dilakukan kepada 6 responden dapat diketahui bahwa kinerja keungan di Klinik Mitra Medika sudah tergolong kedalam kategori sangat baik. Hal ini dapat dibuktikan dengan beberapa kuisioner yang telah peneliti lakukan.

Sehingga didapatkan beberapa indikator dalam kinerja keuangan Klinik Mitra Medika yaitu :

1. Tanggung jawab dengan skor yang didapat 24 dari skor maksimal 30 dengan presentase $80 \%$ dan dikategorikan sangat baik. Tanggung jawab disini diartikan Klinik Mitra Medika mampu memenuhi semua tanggung jawabnya kepada lembaga keuangan yang sah 
seperti membayar pajak, dan mampu memenuhi tanggung jawab berupa laporan keuangan dan deviden kepada pemberi modal.

2. Kemampuan memenuhi kewajiban dengan skor 23 dari skor maksimal 30 dengan presentase $77 \%$ dan dikategorikan baik. Kemampuan memenuhi kewajiban disini diartikan Klinik Mitra Medika mampu memenuhi kewajibannya terhadap pembayaran gaji karyawan, mampu membayar deviden dengan tepat waktu dan mampu memenuhi kebutuhan operasional Klinik.

3. Kejujuran Karyawan dengan skor 27 dari skor maksimal 30 dengan presentasi $90 \%$ dan dikategorikan sangat baik. Kejujuran karyawan disini ditunjukan dengan tidak adanya kejanggalan - kejanggalan di dalam penyajian laporan keuangan Klinik.

4. Efektifitas dan efesiensi modal dengan skor 24 dari skor maksimal 30 dengan presentasi $80 \%$ dan dikategorikan sangat baik. Terbukti dari indikator indikator sebelumnya yang tergolong dalam kategori sangat baik, sudah membuktikan bahwa Klinik Mitra Medika memiliki tingkat pengelolaan keuangan yang efektif dan efisien.

5. Pengendalian Manajemen dengan skor 26 dari skor maksimal 30 dengan presentasi $87 \%$ dan dikategorikan sangat baik. Pengendalian disini diartikan seluruh karyawan telah mengerjakan jobdesknya masing - masing dengan tepat sesuai dengan kewajibannya.

\section{SIMPULAN}

Berdasarkan hasil penelitian yang telah diuraikan dapat disimpulkan bahwa penerapan sistem pengendalian manajemen sangat berpengaruh terhadap kinerja keuangan Klinik Mitra Medika pada masa pandemi Covid-19. Dengan adanya penerapan sistem pengendalian manajemen, Klinik Mitra Medika dapat menggunakan modal dan keuntungan secara efektif dan efisien.

Kinerja keungan di Klinik Mitra Medika ditinjau dengan menggunakan metode skala likers dan menggunakan standar indikator manajemen keuangan yang baik menurut Devas (2007:279) yang mecangkup tanggung jawab (accountability), mampu memenuhi kewajiban, kejujuran karyawan, efektifitas dan efisensi penggunaan modal, dan pengendalian. Hal ini dilihat dari hasil penyebaran kuisioner kepada karyawan menunjukkan bahwa kinerja keuangan Klinik Mitra Medika dikategorikan sangat baik dengan presentase yang di peroleh sebesar $83 \%$.

\section{DAFTAR PUSTAKA}

1. Rohmah, Ulfa Fathu and Kurniawan,

2. Tri Danang (2019) Tingkat Kepuasan Pasien Rawat Jalan Pada Pelayanan Kefarmasian di Klinik Utama Annissa Blitar. Diploma thesis, Akademi Farmasi Putera Indonesia Malang, 4-9. http://repository.poltekkespim.a c.id/id/eprint/454/1/ARTIKEL\% 20ILMIAH\%20PDF.pdf 
3. Ardi Nupi Hasyim, Muhammad dkk (2020) Strategi Peningkatan Kinerja Dengan Metode Balance Scorecard (Studi Kasus Pada Hotel Puri Khatulistiwa Jatinangor), Widya Cipta: Jurnal Sekretari dan Manajemen, 4(2) 147-148.

http://scholar.google.co.id/citati ons?user $=\mathrm{eDZvEWkAAAAJ} \& \mathrm{~h}$ $\underline{1=\mathrm{en}}$

4. Hasrina, Yunita (2015) Analisis Pengelolaan Keuangan Rural Infrastructure Support Program Nasional Pemberdayaan Masyarakat (RIS-PNPM) Di Organisasi Masyarakat Setempat (OMS) Kecamatan Tuah Negeri Kabupaten Musi Rawas, Jurnal Manajemen \& Bisnis Sriwijaya 13(4), 476-477. https://media.neliti.com/media/p ublications/283870-analisispengelolaan-keuangan-ruralinfr-403bc91b.pdf
5. Yustien, Reni Pengaruh Penerapan Sistem Pengendalian Manajemen Pada Pendapatan Dan Pusat Biaya Terhadap Kinerja Manajerial Rumah Sakit Umum Tipe B di Provinsi Jawa Barat, Dosen Jurusan Akuntansi Fakultas Ekonomi Universitas Jambi 46. https://pekbis.ejournal.unri.ac.id /index.php/JPEB/article/view/42 $8 / 422$

6. https://ugm.ac.id/id/berita/19619 -pandemi-covid-19-pengaruhikeuangan-rumah-sakit

7. https://www.google.com/url?q= http://yankes.kemkes.go.id/read/ 132/strategi-rumah-sakit-dimasa-pandemi-covid19\&usg=AOvVaw3t7NjI_oKr3 A5CmjFlYstP

8. https://www.google.com/url?q= https://www.cnbcindonesia.com /news/20200518183459-4159356/duh-arus-kas-rs-swastaberantakan-gegara-pandemicovid-

19\&usg=AOvVaw368EZ3FPAr r_Jyujiy-f9K 